\title{
Smoking Habit Effect on Total Cholesterol Levels
}

\author{
Tri Prasetyorini ${ }^{*}$, Putu Puja Kasih Permata \\ Medical Technology Laboratory Department \\ Health Polytechnic, Ministry of Health Jakarta III \\ Jl. Arteri JORR Jati Warna Pondok Melati Bekasi \\ * Corresponding author's email: tprasetyorini [AT] gmail.com
}

\begin{abstract}
-
Introduction and Aims: Smoking habits have an adverse effect on fat profiles, including high concentrations of LDL cholesterol. Nicotine in cigarettes is one of the substances that interfere with cholesterol metabolism in the body. This study aims to find out more about the relationship of smoking habit to total cholesterol levels.
\end{abstract}

Methods: This research is a survey research using cross-sectional study design. The respondents in this study are active smokerresidents of Bintara XIV. The data collected in this research is using Biosensor method.Analysis of the data performed is univariate and bivariate analysis by using the ANOVA test SPSS for Windows 17.

Result: The result of the ANOVA analysis is $p=0.000(p<0.05)$ which means there is influence of two variables analyzed and there is a relationship between them.

Conclusions: There is influence between smoking habits of respondent with a total cholesterol level of respondent. Respondents with high smoking intensity tend to have high total cholesterol levels. The results of this study are expected to be used as a base for further research todetermine the effect of smoking intensity oneach lipid profile on laboratory examination.

Keywords- Smoking habit, Intensity, Cholesterol Level, Biosensor

\section{INTRODUCTION}

Indonesia became the country with the largest number of smokers in the world after China and India and was ranked the fifth largest cigarette as consumers after China, the United States, Russia, and Japan. Based on data from the Ministry of Health in 1995, the prevalence of an increasing number of smokers reached 27\% and the numbers are rising in 2016 be $36 \%$. Smokers who don't quit before the 35-year-old have a 50\% chance of death due to diseases related to smoking [1].

Another study in 2015 obtained that there is a meaningful relationship between smoking with cholesterol levels, where the number of 60 respondents obtained that $86 \%$ had high cholesterol levels[2].

One of the triggers increased levels of cholesterol is smoking. On Government Decree No. 19 (2003) explained that smoking is a result of processed tobacco, including cigars are wrapped or other materials resulting from plant NicotinaTabacum, Nicotinarustika[3]. The habit of smoking gives bad influence on the fat profile, including a high concentration on LDL cholesterol. The nicotine in cigarettes is one of the substances that interfere with the metabolism of cholesterol in the body. In addition, smoking is also an important risk factor and a major artery and vessel disease and coroner's peripheral disease[4].

Cholesterol is a substance that is needed by the body in certain boundaries for the survival of the cells of the body. Cholesterol is required normally self-produced in the right amount. But cholesterol can also increase if often consume food with animal fat content (cow brains, red meat, seafood, egg yolks, cheese, etc.) and fast food [5].

Increased levels of cholesterol in the blood is a major cause of coronary heart disease. Excess cholesterol levels will react with other substances and react in the arterial blood vessels called atherosclerosis that interfere with blood flow to the heart. Based on the results of basic health Research [6]. Ministry of health 2013, the prevalence of coronary heart disease in Indonesia reached $0.5 \%$ and heart failure of $0.13 \%$ of the population aged 18 years and over [6].

This study aims to find out more about the relationship of smoking habit to total cholesterol levels. 


\section{METHODS}

This is the cross-sectional study to find out the correlation between the intensity of smoking with cholesterol levels, judging whether there is a relationship between the smoking intensity and daily cigarettes consumption with cholesterol levels.

Data retrieval is done after the respondents get a description of the research process and sign for inform consent sheet as a sign of approval.

Furthermore, the respondents have done fasting 10 - 12 hours before checking cholesterol levels using a biosensor. The data collected was analyzed by using SPSS program 17. The analysis is done using the test ANOVA SPSS for Windows 17.

\section{RESULTS}

Research on the influence of smoking intensity against cholesterol levels was done in the Bintara XIV, West Bekasi. The respondents of the research were male and female with the active smokers status who are suitable with the requirements of researchers. As many as 48 respondents have filled out the questionnaire research and cholesterol levels has been tested.

Table 1.The distribution of the influence of the smoking Intensity against cholesterol levels by age of Respondent

\begin{tabular}{|c|c|c|c|c|c|c|}
\hline \multirow[t]{2}{*}{$\begin{array}{l}\text { Age } \\
\text { (Years) }\end{array}$} & \multicolumn{2}{|c|}{$\begin{array}{l}\text { Normal } \\
\text { Levels }\end{array}$} & $\begin{array}{l}\text { High } \\
\text { Levels }\end{array}$ & Cholesterol & \multicolumn{2}{|c|}{$\begin{array}{l}\text { Total } \\
\text { Respondents }\end{array}$} \\
\hline & $\mathbf{N}$ & $(\%)$ & $\mathbf{N}$ & $(\%)$ & $\mathbf{N}$ & $(\%)$ \\
\hline $12-25$ & 2 & 4.2 & 3 & 6.2 & 5 & 10.5 \\
\hline $26-45$ & 15 & 31.2 & 8 & 16.7 & 23 & 47.9 \\
\hline$>45$ & 6 & 12.5 & 14 & 29.2 & 20 & 41.7 \\
\hline Total & 23 & 47.9 & 25 & 52.1 & 48 & 100 \\
\hline
\end{tabular}

Table 1 shows distribution of respondents according to age of 48 respondents who are smokers obtained the respondent with normal cholesterol levels at the age of $12-25$ years as much as 2 respondents (4.2\%), age 26-45 years as much as 15 respondents $(31.3 \%)$, age > 45 years as 6 respondents $(12.5 \%)$. While respondents who have high cholesterol levels as much as 2 respondents at the age of 12-25 (4.7\%), age 26-45 as many as 8 respondents (16.7\%), age $>45$ years as many as 14 respondents $(29.2 \%)$.

Table 2.Influence of smoking Intensity Distribution towards the Total cholesterol levels by gender

\begin{tabular}{lllllll}
\hline Gender & $\begin{array}{l}\text { Normal } \\
\text { Cholesterol } \\
\text { Levels }\end{array}$ & $\begin{array}{l}\text { High } \\
\text { Cholesterol } \\
\text { Levels }\end{array}$ & \multicolumn{2}{l}{$\begin{array}{l}\text { Total } \\
\text { Respondents }\end{array}$} \\
\cline { 2 - 7 } & $\mathbf{N}$ & $(\%)$ & $\mathbf{N}$ & $(\%)$ & $\mathbf{N}$ & $(\%)$ \\
\hline Male & 18 & 37.5 & 19 & 39.6 & 37 & 77.1 \\
Female & 5 & 10.4 & 6 & 12.5 & 11 & 22.9 \\
Total & 23 & 47.9 & 25 & 52.1 & 48 & 100 \\
\hline
\end{tabular}

Table 2 shows the distribution of respondents according to gender from 48 respondents who are smokers, as much of 18 male respondents $(37.5 \%)$ had normal cholesterol levels and 19 respondents $(39.6 \%)$ had high cholesterol levels. As many as 5 female respondents $(10.4 \%)$ had normal cholesterol levels and 6 respondents $(12.5 \%)$ had high cholesterol levels. 
Table 3.Distribution of Smoking IntensityAgainst The Total Cholesterol Levels

\begin{tabular}{lllllll}
\hline $\begin{array}{l}\text { The number } \\
\text { smoking (bar/day) }\end{array}$ & $\begin{array}{l}\text { Normal } \\
\text { Cholesterol } \\
\text { Levels }\end{array}$ & $\begin{array}{l}\text { High } \\
\text { Cholesterol } \\
\text { Levels }\end{array}$ & Total & Respondents \\
\cline { 2 - 7 } & $\mathbf{N}$ & $(\boldsymbol{\%})$ & $\mathbf{N}$ & $(\boldsymbol{\%})$ & $\mathbf{N}$ & $(\boldsymbol{\%})$ \\
\hline $1-4$ & 7 & 14,6 & 0 & 0 & 7 & 14,6 \\
$5-15$ & 10 & 23,3 & 2 & 4,7 & 12 & 28 \\
$>15$ & 6 & 12.5 & 23 & 47.9 & 29 & 60,4 \\
Total & 23 & 47.9 & 25 & 52.1 & 48 & 100 \\
\hline
\end{tabular}

Table 3 about distribution of respondents according to the intensity of smoking shows that from the 48 respondents of smokers, the number of respondents who spent 1-4 cigarettes that had normal cholesterol levels as much as $14.6 \%$ ) respondents $(7$, and a strongly high cholesterol as much as $0(0 \%)$ of the respondents. Then the number of respondents who spent 5-15 cigarettes per day who had normal cholesterol levels by as much as $10(23.3 \%)$ of the respondents, and who have high cholesterol levels as much as $2(4.7 \%)$ of the respondents. While the number of respondents who spend > 15 cigarettes per day had normal cholesterol levels by as much as 6 (12.5\%) of the respondents, and who have high cholesterol levels by as much as $25(52.1 \%)$ respondents.

\section{Bivariate Analysis}

In this study data obtained were analyzed with ANOVA analysis test was processed using the Statistical Product and Service Solution (SPSS) with the following results.

Table 4.Data Normality Test Results

\begin{tabular}{lccccccc}
\hline & \multicolumn{6}{l}{ Kolmogorov-Smirnov ${ }^{\mathrm{c}}$ Shapiro-Wilk } \\
\cline { 2 - 7 } & Statistics & df & sig. & Statistics & df & sig. \\
\hline $\begin{array}{l}\text { Cholesterol levels of total } \\
\text { respondents }\end{array}$ & 093. & 48 & $200 .{ }^{*}$ & 974. & 48 & 347. \\
\hline
\end{tabular}

The test of normality of the data used is the Shapiro Wilk due to the number of respondents is less than 50 people. Test results of Shapiro Wilk obtained that the data is normally distributed with $\mathrm{p}$ value $>0.05$. So that the test used was ANOVA SPSS for Windows 17.

Table 5.Statistical Results of Smoking Intensity Against The Influence of The Levels of Total Cholesterol

\begin{tabular}{llllll}
\hline & Sum of Squares & df & Mean Square F & sig. \\
\hline Between Groups & $72,148,642$ & 2 & $36,074,321$ & 24,089 & .000 \\
\hline Within Groups & $67,389,275$ & 45 & $1,497,539$ & & \\
\hline Total & $139,537,917$ & 47 & & & \\
\hline
\end{tabular}

Based on the statistical tests by using the test ANOVA SPSS for Windows 17 between the levels oftotal cholesterol in the group the smoking intensity obtained $\mathrm{p}$ value $=0000(\mathrm{p}<0.05)$.

\section{DISCUSSION}

Total cholesterol levels obtained from the examination using a stick test total cholesterol to the previous respondents to fast for eight hours. High total cholesterol levels if less than $200 \mathrm{mg} / \mathrm{dl}$ andhigh cholesterol levels if more than 200 $\mathrm{mg} / \mathrm{dl}$. 
Table 1 on the results of the study showed that from 48 respondents, mostly smokers are at the range of age $26-45$ years as many as 23 people (47.9\%), high cholesterol levels mostly onrespondents aged elderly above 45 years, that as many as 20 persons $(29.2 \%)$. While table 2 on the results of the study showed that from 48 respondents, most of the respondents who are smokers are men, as many as 37 people $(77.1 \%)$.

This is in accordance with the opinion of [7]. that high and low cholesterol levels are affected bymetabolism in the body. After reaching the age of 20 years old, cholesterol levels usually tend to rise. Cholesterol levels in men, generally continuously increased after the age of 50 years. In females, cholesterol levels will stay down inmenopauseperiod, after that the cholesterol levels tends to be higher in men.

The woman will lose 30 to 50 percent of the total muscle mass at the age of 45 years. Due to the aging process, the body's metabolism will naturally slow down and low mobility accelerates the process of replacement of muscle mass with body fat. The decrease in muscle mass helps to reduce calorie consumption and almost every food is converted into fat [8].

In this study was obtained by the respondent who spent 1-4 cigarettes that have normal cholesterol levels by as much as $7(16.3 \%)$ of the respondents, and who have high cholesterol levels by as much as $0(0 \%)$ of the respondents. Then the number of respondents who spent 5-15 cigarettes per day had normal cholesterol levels by as much as $10(23.3 \%)$ of the respondents, and who have high cholesterol levels as much as $2(4.7 \%)$ of the respondents. While the number of respondents who spend $>15$ cigarettes per day had normal cholesterol levels by as much as $2(4.7 \%)$ of the respondents, and who have high cholesterol levels as much as $24(51.2 \%)$ respondents. It brings the total cholesterol level differences are significant between respondents who spend 1-4 cigarettes per day, 5-15 cigarettes per day, and > of 15 cigarettes per day.

From the analysis results with the test ANOVA SPSS for Windows 17 obtained as a result of the form $\mathrm{p}=0.000(\mathrm{p}<$ $0.05)$ which means there is the influence of two variables were analyzed and there is relation between the two variables. So the more the number of cigarettes smoked the higher total cholesterol levels of the respondent.

The results of this study in accordance with research, that increased levels of total cholesterol are not significant found on light smokers, whereas a significant increase was found in medium and heavy smokers. According nicotine which is a major component of smoking can increase the secretion of katakolamin which increases lipolysis. This leads to increased levels of cholesterol and VLDL, trigliseryde, as well as lowering the levels of HDL. Smoking can also cause an increase in LDL cholesterol oxidation that will lead to atherosclerosis. Cigarettes contain nicotine which can stimulate an increase in blood pressure and activates platelets cause the coagulation on the wall of blood vessel . Nicotine, carbon monoxide and other materials contained in cigarette smoke can damage blood vessel walls. Nicotine, $\mathrm{CO}$, and other ingredients in cigarette smoke proved to be damaging to endothelial (blood vessel wall), in addition, cigarette smoke affects the fat profile. Research conducted the stated that smoking can increase insulin resistance and fat accumulation is associated with the Center.

Cigarettes contain many harmful elements, such as the nicotine effect on the heart, increase blood clotting and ultimately increase the blood levels of LDL cholesterol and lower HDL cholesterol levels in blood. Long-term nicotine consumption can raise LDL cholesterol and a decrease in HDL cholesterol. In smokers, nicotine is believed can release catecholamines, increase lipolysis, and increased free fatty acids. With the increase of free fatty acids make the production of excessive LDL cholesterol and LDL production with excessive blood levels of HDL cholesterol then by itself will decrease [9].

In smokers, nicotine stimulates the secretion of Catecholamines. This hormone increase FFA by lipolysis. FFA to reach the hearts of the diesterifikasi as triacylglycerols and cholesterol esters are secreted into the blood stream as VLDL that is converted into circulating LDL in the blood [8]. Acrolein may damage the HDL so annoying task of HDL in collecting bad cholesterol or LDL. HDL levels decrease LDL allows to stack and move freely. in the blood stream. Acrolein triggers a process that alters the molecular structure of LDL so that made it is not recognized.

Based on the results in the table above also found that high cholesterol levels on the respondent with the intensity of the light smoking itensity and normal cholesterol levels on respondents with heavy smoking intensity , this is because besides smoking there are any kind of the other things can affect the levels of total cholesterol respondents such as lifestyle and consumption of foods containing cholesterol.

\section{CONCLUSIONS}

Based on the results of the research, it can be inferred that there is an influence of smoking intensity among respondents with a total cholesterol level of the respondents. Respondents with high smoking intensity tend to have a high total cholesterol levels. 
Smoking is a bad habit that is very difficult to avoid. Based on the results of the study, pointed out that smoking and the smoking intensity affect the levels of total cholesterol in the blood. So it is highly recommended to avoid and reduce the consumption of cigarettes in order to reduce the factor causes increased levels of cholesterol that can lead to various diseases such as coronary artery disease and stroke.

For further research that will examine the same topic, the exclusion and inclusion criterias should be expanded, so that the respondents involved later will be able come from different status of nutrition value. And also to know the influence of intensity of smoking against the cholesterol levels in more detail, it's good to do research on the influence of smoking on the intensity of each type of cholesterol.

\section{ACKNOWLEDGEMENTS}

Ethical clearance for this study was granted by Health Polytechnic Ministry of Health Jakarta III.

\section{REFERENCES}

[1] Khotijah, Umi, 'Pengaruh Pemberian Ekstrak Lidah Buaya Terhadap Kadar Kolesterol Hdl Dan Ldl Serum Tikus Putih Hiperkolesterolemi 'Skripsi, Universitas Negeri Semarang, 2007.

[2] Kusumasari, Peni, 'Hubungan Antara Merokok Dengan Kadar Kolesterol TotaL pada Pegawai Pabrik Gula Tasik madu Karanganyar’. Skripsi, Universitas Muhammadiyah. Surakarta, 2015

[3] PP RI No. 19 tahun , "Pengamanan rokok bagi kesehatan", 2003

[4] Devaranavadgi B. B, dkk. . 'Cigarette Smoking on Blood Lipids' -Study in Belgaum. Northern Karnataka.India. Global Journal Inc Vol.12 Issue 6. USA.2001

[5] LIPI, "Kolesterol.UPT- Balai Informasi Teknologi LIPI "Pangan dan Kesehatan”, 2009

[6] Riset Kesehatan Dasar (RISKESDAS), "Badan Penelitian dan Pengembangan Kesehatan, Departemen Kesehatan” Republik Indonesia. Desember, 2011

[7] Joewono, B.S, .Ilmu Penyakit Jantung, Airlangga University Press. Surabaya, 2007

[8] Ujiani S, "Hubungan antara usia dan jenis kelamin dengan kadar kholesterol penderita obesitas RSUD Abdul Moeloek provinsi Lampung”, Jurnal Kesehatan, 6(1), 43-48, 2015

[9] Sanhia, A.M. Pangemanan, D, dan Engla, "Gambaran kadar cholesterol Low Density lipoprotein" E.biomedik (eBm), 3 (april), 460-465, 2015 